\title{
STUDI FENOMENOLOGI PENGALAMAN ORANG TUA DALAM MEMANDIRIKAN ANAK USIA (0-18 TAHUN) DENGAN RETARDASI MENTAL SEDANG DI SLB NEGERI BATULICIN KABUPATEN TANAH BUMBU 2019
}

\author{
*Rahmadayanti, Nadia S ** Atmaja, Bayu Purnama ${ }^{* * *}$ Udiyani, Ritna \\ ${ }^{1}$ Program Studi Ilmu Keperawatan STIKes Darul Azhar Batulicin,Tanah Bumbu, 72171, Indonesia \\ ${ }^{2,3}$ Staf Pengajar Program Studi Ilmu Keperawatan STIKes Darul Azhar Batulicin, Tanah Bumbu, \\ 72171, Indonesia
}

Email: solehahnadia123@gmail.com

\begin{abstract}
ABSTRAK
Latar Belakang: Retardasi mental adalah sebuah keadaan intelegensi yang kurang (subnormal) sejak awal masa perkembangan (sejak lahir atau sejak masa anak). Masalah yang sering terjadi pada anak seperti kelemahan dan keterbatasan dalam kemampuan kemandirian misalnya dalam hal mengurus diri (oral hygiene, mandi, berpakaian), serta kemandirian toileting membutuhkan peran penting dari orang tua. Penelitian ini bertujuan untuk mengeksplorasi pengalaman orang tua dalam memandirikan anak retardasi mental di SLB N Batulicin.

Metode: Penelitian ini merupakan penelitian kualitatif dengan rancangan penelitian menggunakan pendekatan fenomenologi. Sampel penelitian berjumlah 5 orang partisipan. Instrumen penelitian menggunakan pedoman wawancara dan alat perekam berupa handphone.

Hasil: Hasil penelitian berdasarkan pengalaman dari orang tua dalam memandirikan anak retaradasi mental memiliki tiga tema antara lain : reaksi psikologis orang tua, melatih kemandirian anak retardasi mental, dan berbagai dukungan yang di harapkan orang tua.

Kesimpulan dari ketiga tema penelitian tersebut adalah dukungan keluarga memiliki peran paling penting bagi orang tua dalam mengasuh dan mendidik anak dengan retardasi mental, sehingga dapat memberikan efek positif bagi orang tua untuk menerima dan melatih segala kekurangan pada anak retardasi mental. Disarankan kepada orang tua yang memiliki anak retardasi mental agar dapat meningkatkan kemandirian anak dengan membimbing, memberi contoh dan mengarahkan anak dengan benar dalam melakukan kegiatan aktivitas setiap harinya.
\end{abstract}

Kata kunci : Memandirikan, Pengalaman orang tua, Retardasi mental 


\section{PENDAHULUAN}

Menurut Mangunsong (2011), anak yang berkebutuhan khusus salah satunya ialah anak dengan retardasi mental (tuna grahita) yang mempunyai kemampuan intelektual dibawah rata-rata dan tingkat kelainan ringan, berat dan sangat berat yaitu dengan IQ 70-25. Salah satu jenis retardasi mental/tunagrahita yang sering muncul adalah anak down syndrome.

Data Sensus Nasional Biro Pusat Statistik (BPS) tahun 2010 menyatakan bahwa jumlah penyandang cacat di Indonesia adalah sebesar $0,7 \%$ dari jumlah penduduk sebesar 211.428.572 atau sebanyak 1.480.000 jiwa. Sebanyak $24,45 \%$ dari jumlah tersebut atau 361.860 diantaranya adalah anak-anak usia 018 tahun dan $21,42 \%$ atau 317.016 anak merupakan anak cacat usia sekolah (5-18 tahun). Sekitar 66.610 anak usia sekolah penyandang cacat $(14,4 \%$ dari seluruh anak penyandang cacat) ini terdaftar di Sekolah Luar Biasa (SLB) (Kementrian Kesehatan, 2017).

Pada anak dengan retardasi mental terdapat beberapa masalah yang terjadi seperti kelemahan atau ketidakmampuan pada anak sebelum memasuki usia 18 tahun yang disertai keterbatasan dalam kemampuan kemandirian misalnya dalam hal, mengurus diri (oral hygiene, mandi, berpakaian) dan kemandirian dalam hal toilet training (Sari, 2016).

Anak mengalami proses pertumbuhan dan perkembangan. Pertumbuhan dilihat dari bertambahnya ukuran fisik anak, sedangkan perkembangan dilihat dari kognitif anak. Dalam masa perkembangan, jika anak memiliki gangguan perkembangan yang ditandai dengan IQ yang rendah maka anak itu mengalami retardasi mental. Retardasi mental adalah suatu keadaan perkembangan mental yang terhenti atau tidak lengkap, yang terutama ditandai oleh adanya hendaya (impairment) ketrampilan (kecakapan, skills) selama masa perkembangan, sehingga berpengaruh pada semua tingkat intelegensia, yaitu kemampuan kognitif, bahasa, motorik, dan sosial. Retardasi mental dapat terjadi dengan atau tanpa gangguan mental atau fisik lainnya (Anam, 2017).

Tanggapan negatif masyarakat tentang anak retardasi mental menimbulkan berbagai macam banyak reaksi orang tua yang memiliki anak retardasi mental, seperti orang tua mengucilkan anak atau tidak mengakui anak yang menderita retardasi mental. Anak yang menderita retardasi mental disembunyikan dari masyarakat karena orang tua merasa malu mempunyai anak yang keterbelakangan mental. Di sisi lain, ada pula orang tua yang memberikan perhatian yang lebih pada anak retardasi mental. Orang tua yang menyadari memiliki anak dengan retardasi mental berusaha memberikan yang terbaik pada anaknya dengan meminta bantuan pada ahli yang dapat menangani anak retardasi mental. Orang tua yang memahami dan menyadari akan kelemahan anak retardasi mental merupakan faktor utama untuk membantu perkembangan anak dengan lingkungan (Sari, 2016).

Reaksi pertama orang tua ketika anaknya dikatakan bermasalah adalah tidak percaya, shock, sedih, kecewa, mersa bersalah, marah dan menolak. Tidak mudah bagi orang tua yang anaknya menyandang kecacatan untuk mengalami penerimaan. Ada masa orang tua merenung dan tidak mengetahui apa yang harus diperbuat. Tidak sedikit orang tua yang kemudian memilih tidak terbuka mengenai keadaan anaknya kepada teman, tetangga, bahkan keluarga dekat sekalipun, kecuali kepada dokter yang menangani anaknya tersebut (Zaviera, 2010).

Pengalaman orang tua tidak hanya cukup memberi makan, minum dan berpakaian saja kepada anak-anaknya, tetapi keseluruhan atau totalitas segala pengamatan, yang disimpan didalam ingatan dan digabungkan dengan suatu pengharapan akan masa depan, sesuai dengan apa yang telah diamati pada masa lampau. Akan tetapi orang tua juga harus memberikan kasih sayang, perhatian, dan dukungan terhadap anak yang terlahir secara tidak normal. Sehingga anak mempunyai semangat untuk masa depannya (Zaviera, 2010). Semiun (2009) dalam penelitiannya juga mengatakan hubungan anak retardasi mental dengan orang tuanya sangat penting dibandingkan dengan hubungan anak yang intelegensinya normal dengan orang tuanya. 
Berdasarkan studi pendahuluan yang dilakukan di Sekolah Luar Biasa Negeri Batulicin, Kabupaten Tanah Bumbu pada tanggal 26 Februari 2019, didapatkan jumlah anak di Sekolah Luar Biasa sebanyak 85 anak yang terdata di Sekolah Luar Biasa. Hasil wawancara dari 5 orang tua yang memiliki anak usia 8 tahun diperoleh keterangan bahwa 5 (50\%) ibu mengatakan bahwa anaknya masih sering dibantu dalam menggunakan pakaian dengan alasan praktis dan tidak repot karena anaknya masih sulit untuk dilatih dalam berpakaian sendiri dan terlalu lama, $1(10 \%)$ ibu yng mengatakan bahwa anaknya menangis dan marah saat melakukan berpakaian sendiri tanpa bantuan ibunya dan 4 (40\%) ibu yang mengatakan bahwa anaknya mampu dilatih menggunakan pakaian sendiri walau sering dibantu sedikit-sedikit dan anak terkadang susah untuk diajarkan dalam melakukan suatu kegiatan aktivitas yang akan membuatnya mandiri sehingga orang tua sering melakukan pada saat anak ingin dan waktu senggang orang tua saat mengajarkan anak untuk mandiri sehingga jika dibiarkan terus menerus maka akan menimbulkan dampak yang akan terjadi pada anak retardasi mental jika tidak dilakukan latihan terus menerus dalam melatih kemandiriannya maka anak akan menjadi masalah bagi keluarga dan sering tergantung pada orang lain dalam melakukan setiap aktivitasnya.

\section{METODE}

Lokasi Penelitian ini dilakukan di SLB Negeri Batulicin Kabupaten Tanah Bumbu. Waktu pelaksanaan Penelitian ini pada tanggal Juni - Juli 2019. Penelitian ini menggunakan metode kualitatif dengan pendekatan fenomenologi. Penelitian kualitatif bermaksud memahami fenomena tentang apa yang dialami oleh subjek penelitian misalnya perilaku, persepsi, motivasi, tindakan secara holistik dan dengan cara deskripsi dalam bentuk kata-kata dan bahasa, pada suatu konteks khusus yang alamiah dengan memanfaatkan berbagai sumber alamiah (Moleong, 2014).

Penelitian ini dilakukan untuk mengekplorasi pengalaman orang tua dalam memandirikan anak retardasi mental. Menurut Sugiyono (2010) metode kualitatif dipilih karena banyak hal yang tidak dapat ditelaah dengan menggunakan metode peneltian kuantitatif. Metode ini berguna untuk pemahaman yang lebih mendalam tentang makna (arti subjectif dan penafsiran) dan konteks tingkah laku serta proses yang terjadi pada faktor-faktor yang berkaitan dengan tingkah laku tersebut.

\section{HASIL}

\section{Karakteristik responden}

Sebanyak lima orang tua diwawancarai dari bulan September 2019 sampai dengan bulan Oktober 2019. Lima orang di data untuk terlibat dalam penelitian ini. Pengecekan dan validasi hasil wawancara dilakukan pada awal oktober 2019. Adapun jenis kelamin dari partisipan terdiri dari satu laki-laki dan empat perempuan yang mana usia partisipan bervariasi antara 30 tahun sampai dengan 45 tahun. Dalam menjalankan tugasnya sebagai orang tua sebagian besar partisipan memiliki latar belakang pendidikan SD, SMP dan SMA

\section{Analisis Tematik}
a. Berbagai Dukungan Dalam Memandirikan Anak Retardasi Mental.
b. Melatih Kemandirian Anak Retardasi Mental Sedang.
c. Reaksi Orang Tua Dalam Memandirikan Anak Retardasi Mental

\section{PEMBAHASAN}

Orang tua yang memiliki anak dengan retardasi mental (tunagrahita) akan memperlihatkan respon psikologis yang bermacam-macam dan berbeda-beda. Penelitian yang dilakukan Anam (2017) menyatakan bahwa orang tua langsung merasa stres, tetapi pada penelitian yang dilakukan oleh peneliti terhadap lima partisipan melalui wawancara mendalam muncul beberapa respons psikologis diantaranya merasa kaget, merasa syok dan merasa pasrah. Berikut ungkapan dari partisipan :

“...Ya kaget juga kita kan seperti ini apa yo dulunya itu sakit tarus lo...”(P1)

"...kemaren tu(itu) cuman sedikit syok, habis(setelah) tu(itu) perlahan lahan hilang..." (p3) 
Dalam penelitian ini orang tua mengalami proses penerimaan dalam menerima keadaan yang terjadi pada anak. Orang tua masuk dalam proses denial yaitu, merasa kaget, merasa syok dan merasa pasrah. Pada proses ini apa yang dirasakan oleh orang tua sangatlah wajar, karena ini adalah proses penerimaan dimana setiap orang yang mengalami hal yang diluar dengan apa yang diharapkan apalagi itu menyangkut dengan suatu hal yang penting didalam hidupnya pasti akan berat jika harus menerima kenyataan seperti ini yaitu memiliki anak dengan retardasi mental. Perasaan orang tua saat mengetahui anak mereka mengalami retardasi mental beberapa dari orang tua mengungkapkan bahwa mereka sedih dengan kenyataan yang terjadi.

Biasanya hal ini terjadi pada saat orang tua ingin memandirikan sang anak dan anak juga ada keterbatasan dalam melakukan kegiatan sehari-hari jadi orang tua merasakan kembali kesedihan itu. Ada juga yang mengungkapkan sampai saat ini masih merasa sedih tapi mau bagaimana lagi karena menurut orang tua anak adalah titipan dari Tuhan Yang Maha Esa jadi mereka harus menerima anak dengan kondisi seperti apapun dan mereka hanya bisa ikhlas dengan semua yang Tuhan berikan. Disini ada juga respon orang tua yang mengatakan syok dan kaget terhadap anak, hal ini dikarenakan sang anak yang lambat untuk mengerti apa yang diajarkan orang tua pada saat mereka melakukan kegiatan sehari-hari dan jika orang tua sedang sibuk dengan pekerjaannya dirumah sang anak tidak bisa mandiri dan selalu meminta bantuan kepada orang tua. Peneliti memiliki asumsi bahwa adanya reaksi emosional yang dirasakan oleh orang tua anak pada saat pertama kali mengetahui anaknya memiliki berkebutuhan khusus sangatlah manusiawi, reaksi emosional yang dialami orang tua anak disini adalah perasaan kaget, maka dari itu munculah berbagai respon pada orang tua. Pada penelitian Suri (2017) mengatakan bahwa yang terjadi antara lain: menerima, tidak percaya, sedih, kaget, marah dan khawatir. Sama halnya dengan respon orang tua pada penelitian ini yaitu, merasa sedih dan kaget dengan keadaan anaknya.

Orang tua harus mempunyai kemampuan yang lebih mendalam dan penerimaan yang kuat dalam mengasuh, mendidik dan memandirikan anak retardasi mental. Hal tersebut tentu mengharuskan menemukan hal yag lebih spesifik terkait permasalahan yang dialami orang tua sehingga dapat dijadikan dasar untuk mendidik anak secara mandiri.

Melatih kemandirian anak retardasi mental dengan cara dilakukan berulangulang serta memberikan contoh melakukan kegiatan yang benar dan memberikan instruksi kepada anak dalam melakukan kegiatannya secara mandiri seperti: makan, mandi, berpakaian dan aktivitas yang bisa di lakukan anak. Dengan kata lain ada kemungkinan peran sebagai orang tua tidak dapat dilaksanakan dengan optimal. Hasil wawancara yang dilakukan mendapatkan data bahwa dalam peran sebagai orang tua sangat diperlukan dan di jadikan sebagai pendidik utama, termasuk membimbing anak menghadapi dunia kehidupan. Berikut ungkapan dari partisipan :

“...kalau untuk kemandiriannya setiap hari setiap saat setiap waktu kita kita kasih kita didik dia kemandirian..." (P2)

"....kalau mandirinya sudah bisa makai(pakai) celana sendiri cuman di bantu kalau makai celana dalam karenakan sering tegulung..."(P3)

Anak-anak belajar dari kehidupan di dalam keluarganya. Semenjak anak tersebut mulai masuk kesekolah, orang tua tetap harus memberikan perhatian penuh perkembangan anak, tidak lantas hanya memberikan tugas sebagai pendidik anak kepada para guru di sekolahnya. Guru memang bertugas sebagai pendidik di sekolah, tetapi setelah pulang kerumah orang tuanya lah satu-satunya pendidik yang paling baik bagi anak (Anam, 2017).

Hal ini sesuai dengan pernyataan Monteiro \& Simbolon (2014) yang secara spesifik menyampaikan bahwa ternyata waktu tertinggi yang dihabiskan oleh orang tua dalam menjalankan tugasnya dalam mengasuh anak dan mendidik anak merupakan fungsi yang terberat maka 
orang tua tentunya memerlukan bantuan dari dukungan keluarga.

Orang tua berperan penting dalam perkembangan anak retardasi mental. Semakin dekat orang tua dengan anak, semakin orang tua dapat mengetahui permasalahan yang terjadi pada anak. Di lingkungan keluarga merupakan tempat yang baik untuk melatih keterampilan anak sejak dini, orang tua sudah selayaknya memberikan pendidikan secara non formal yang akan mempengaruhi terhadap kemandirian anaknya (Samsuri, 2016).

Anggraeni (2016) berpendapat bahwa peran terpenting dalam memandirikan anak yang mengalami retardasi mental adalah terutama seorang ibu. Ibu berperan sebagai mengasuh dan mendidik anak. Selain itu ibu mempunyai peran sebagai pengurus rumah tangga dan orang yang paling dekat atau yang paling sering berhubungan dengan anak dalam keluarga, sehingga sikap ibu merupakan faktor yang penting dalam perkembangan anak, khususnya anak yang mengalami retardasi mental. Anak yang mengalami retardasi mental membutuhkan perhatian khusus dari orang tua berupa membantu anak retardasi mental agar timbul sikap percaya diri untuk berkomunikasi kepada orang tua maupun orang lain, serta dapat mandiri terhadap perawatan dirinya. Kepercayaan diri orang tua juga sangat penting untuk membantu atau merawat anaknya yang mengalami retardasi mental, faktor-faktor yang dapat membangkitkan rasa kepercayaan diri orang tua anak retardasi mental adalah faktor lingkungan, faktor harga diri, dan faktor sikap (Ayu, 2019).

Hasil penelitian ini menggambarkan bahwa setiap dukungan dari berbagai sumber merupakan suatu kekuatan bagi orang tua dalam memandirikan anak retardasi mental. Dukungan ini merupakan sumber yang dapat mempengaruhi keberhasilan suatu tujuan yang ingin diharapkan. Berikut ungkapan dari partisipan :

“...dorongan dari keluarga sekitar seperti tetangga - tetangga, teman-teman justru mereka itu yang menguatkan..." (P2) "...dari keluarga kalau bapa dan keluarga yang jauh tukan nanya keapa(bagaimana) keadaan(kondisi) anak sekarang..."(P4)

Dukungan adalah informasi atau umpan balik dari orang lain yang menunjukkan bahwa seseorang merasa di hargai, dicintai dan di perhatikan yang menjadi umpan balik (King, 2016). Dukungan informasional Keluarga berfungsi sebagai sebuah kolektor dan diseminator (penyebar) informasi tentang dunia. Menjelaskan tentang pemberian saran, sugesti, informasi yang dapat digunakan mengungkapkan suatu masalah. Dukungan yang diwujudkan dalam bentuk afeksi, adanya kepercayaan, perhatian, mendengarkan dan didengarkan dapat menjadikan semangat orang tua dalam melatih dan mendidik anak. Sehingga hal dukungan keluarga dengan cara emosional terhadap kemandirian anak retardasi mental sedang. Keluarga sebagai tempat yang aman dan damai untuk istirahat dan pemulihan serta membantu penguasaan terhadap emosi. Aspek-aspek dari dukungan keluarga meliputi dukungan yang diwujudkan dalam bentuk kekuatan, adanya kepercayaan, perhatian, mendengarkan dan didengarkan. Ini didukung oleh hasil penelitian yang dilakukan oleh Muliana (2016) menunjukkan bahwa dengan adanya perhatian keluarga bisa memberikan rasa aman dan damai jika anak sedang merasa sedih, dan merasa sendiri.

Adanya dukungan keluarga yang diberikan orang tua terhadap anak dengan ungkapan simpati, rasa peduli dan perhatian akan memberikan rasa aman sehingga anak tidak merasa terasingkan dalam keluarga, karena hal pertama yang perlu diberikan kepada anak dengan retardasi mental adalah kepercayaan diri dalam melakukan sesuatu. Caranya, orang-orang terdekat harus slalu memberi pujian atas apa yang telah dilakukan, meskipun hasilnya tidak sempurna. Cara seperti itu akan membuat si anak merasa apa yang dia lakukan sudah benar, sehingga timbul rasa percaya diri, berani tampil di depan orang lain.

Hasil pemaparan diatas dapat disimpulkan bahwa ada hubungan dukungan keluarga seperti dukungan 
informasional, dukungan penilaiaan, dukungan lingkungan, dan dukungan kesehatan terhadap kemandirian anak retardasi mental sedang yang mengalami keterbelakang intelegensi atau pikiran, yang mengakibatkan mereka memiliki kekurangan dalam banyak hal yakni: kemampuan untuk mempelajari informasi dan keterampilan menyesuaikan diri dengan masalah-masalah dan situasi-situasi kehidupan baru. Dari kesimpulan yang ada maka peneliti berasumsi bahwa orang tua mempunyai pegangan untuk menerima apapun kekurangan atau kelebihan anak. Selain itu dukungan keluarga juga sangat berperan penting terhadap kemandirian anak.

Penelitian ini telah mengidentifikasi pengalaman orang tua dalam memandirikan anak retardasi mental menggunakan metode kualitatif fenomenologi. Metode yang digunakan ini dapat dijadikan sebuah pengembangan instrument pengkajian aspek psikologis pada orang tua yang merawat anak. Selain itu, hasil penelitian ini perlu pengembangan penelitian lebih lanjut terhadap upaya meningkatnya perawatan anak dengan retardasi mental.

\section{KESIMPULAN}

Kesimpulan dari penelitian ini dari ketiga tema tersebut adalah dukungan keluarga dalam pengalaman orang tua memandirikan anak retardasi mental memiliki peran paling penting untuk orang tua dalam mengasuh dan mendidik anak dengan retardasi mental, sehingga dapat memberikan efek positif bagi orang tua untuk menerima dan melatih segala kekurangan pada anak retardasi mental.

Diharapkan bagi partisipan yang mempunyai anak retardasi mental dapat sering-sering melatih dan memberikan arahan serta didikan untuk anak dapat bisa menjadi anak yang mandiri. Dan untuk peneliti selanjutnya agar dapat melakukan penelitian lebih mendalam tentang dukungan keluarga terhadap proses kemandirian pada anak retardasi mental.

\section{ACKNOWLEDGMENT}

Ucapan terimakasih yang sebesarbesarnya dengan segala kerendahan hati peneliti kepada dosen pembimbing, penguji laporan skripsi dan kepala sekolah SLB N Batulicin tempat dilaksanakannya penelitian.

\section{DAFTAR PUSTAKA}

A. Wahab Samik. 1999. Ilmu Kesehatan Anak Nelson. 15th ed. Jakarta: EGC;

Afiyanty. 2014. Metodologi Penelitian Kualitatif Dalam Riset Keperawatan. 1st ed. Jakarta: Rajawali Pers.

Alwisol. 2018. Psikologi Kepribadian. Malang: Universitas Muhammadiyah Malang; http://books.google.co.id.

Accessed July 27, 2019.

Anam. 2017. Sikap Orang Tua Dalam Penanganan Anak Reterdasi Mental Di SLB Negeri Bendo Kecamatan Kepanjen Kidul Kota Blitar. J Ners Dan Kebidanan.;4.

Andriana. 2013. Tumbuh Kembang Dan Terapi Bermain Pada Anak. Jakarta: salemba medika.

Anisa. 2017. The Correlation Of Knowledge And Parent's Attitude To The Independency Of Mild Mental Reterdation Childrend At Elementary School Of Special Needs Childeren (SLBN). J Akad Baiturrahim.;6. http://stikba.ac.id. Accessed June 28, 2019.

Ayu F. 2017. Peran Keluarga Dalam Memandirikan Aanak Retardasi Mental Di Aceh. Univ Syiah Banda Aceh. http://jim.unsyiah.ac.id. Accessed July 26, 2019.

Charles. 2016. Dissent, Revolution And Liberty Beyond Earth.;. 
Dinas Kesehatan Kota Banjarmasin. 2017. Profil Kesehatan Kota Banjarmasin Tahun 2017. Banjarmasin: Dinas Kesehatan Kota Banjarmasin.

Dinas Kesehatan Kota Malang. 2012. Profil Kesehatan Kota Malang Tahun 2012. Malang: Dinas Kesehatan Kota Malang 2012.

Dinas Kesehatan Kabupaten Sukoharjo. 2015. Profil Kesehatan Kabupaten Brebes Tahun 2014 Lingkungan Sehat Rakyat Sehat. Sukoharjo: Dinas Kesehatan Kabupaten Sukoharjo.

Dinas Kesehatan Kabupaten Tanah Bumbu. 2017. Data Penyakit Gastritis Ksbupsten Tanah Bumbu 2017.

Djam'an Satori dan Komariah. 2013. Metodologi Penelitian Kualitatif. 5th ed. Bandung: Alfabeta, $\mathrm{Cv}$.

Ervina S. 2016. Gambaran Kemandirian Pada Remaja Tunagrahita Ringan Di Yayasan Pembinaan Anak Cacat (YPAC) Medan Sumatra Utara. http://repository.uhn.ac.id. Accessed July 13, 2019.

Furohmiyantiningsih. 2015. Pengalaman Orang Tua Dalam Memandirikan Personal Hygiene Anak Prasekolah Di Susun Dondong Tegaltirto Berbah Sleman. http://digilib.unisayogya.ac.id. Accessed July 6, 2019.
Hardi \& Huda, Amin. (2015). Asuhan Keperawatan Berdasarkan Diagnosa Medis \& NANDA. Yogyakarta : Mediaction Publishing.

Rohana. 2015. Adult Nursing Practice: Using Evidence in Care "Holistic Nursing in Emergency and Disaster: Issue and Future." Jurusan Keperawatan FK UNDIP; http://eprints.undip.ac.id.

Accessed June 7, 2019.

Samsuri. 2016. Gambaran Pengalaman Orang Tua Dalam Memandirikan Anak Reterdasi Mental Di SLBN Surakarta.

Sari. 2016. Gambaran Pengalaman Strees dan Koping Orang Tua Yang Memiliki Anak Dengan Reterdasi Mental.

Sartika. 2017. Hubungan Peran OrangTua Dengan Tingkat Kemandirian Activity Daily Living (Adl) Pada Anak Dengan Retardasi Mental Di Kabupaten Sleman.. http://repository.unjaya.ac.id. Accessed July 24, 2019.

World Health Organization. 2013. WHO Report On The Global Tobacco Epidemic 2013. Geneva : WHO

WHO. Facth sheet Tobacco [Online] 2008. Dari : http://www.who.int [8 Februari 2015]. 